\title{
A STUDY OF THE BONDING OF WOOD FROM Eucalyptus grandis W. Hill ex Maiden USING RESORCINOL-FORMALDEHYDE ADHESIVE
}

\author{
Vanessa Cristina do Sacramento Albino ${ }^{1}$, Fábio Akira Mori² ${ }^{2}$ Lourival Marin Mendes ${ }^{3}$
}

(received: September 30, 2009; accepted: July 29, 2010)

\begin{abstract}
This work aims to evaluate the strength of joints bonded with thermosetting resorcinol-formaldehyde adhesive, as obtained from three radial and three longitudinal positions relative to the log in wood of Eucalyptus grandis W. Hill ex Maiden (Myrtaceae) at age 18 years, and also to correlate it with basic density. The adhesive spread rate was $250 \mathrm{~g} / \mathrm{m}^{2}$ using double lines and adding hardener at a rate of one part of hardener to five parts of adhesive. Moisture content in the wood sheets at the time of bonding was $12 \%$. Bonded joints were prepared according to standard ASTM D 2339-98. Basic density values showed an increasing tendency in the pith-to-bark direction while no significant variation was noted in the base-to-top direction. Higher mean values of shear strength and smaller percentages of wood failure were obtained from joints originated in positions close to the bark and to the log base. Overall, the bonding behavior of resorcinol-formaldehyde adhesive in Eucalyptus grandis was found to vary considerably in different positions relative to the $\log$.
\end{abstract}

Key words: Eucalypt, bonded joints, thermosetting.

\section{ESTUDO DA COLAGEM DA MADEIRA DE Eucalyptus grandis W. Hill ex Maiden COM ADESIVO RESORCINOL-FORMALDEÍDO}

\begin{abstract}
RESUMO: Neste trabalho, objetivou-se avaliar a resistência de juntas coladas com adesivo termoendurecedor resorcinol-formaldeído provenientes de três posições radiais e três posições longitudinais da tora da madeira de Eucalyptus grandis W. Hill ex Maiden (Myrtaceae), com idade de 18 anos, relacionando-a com a densidade básica. A gramatura utilizada foi de $250 \mathrm{~g} / \mathrm{m}^{2}$, em face dupla, com adição de endurecedor, na proporção de uma parte para cinco partes de adesivo. A umidade das lâminas, no momento da colagem, era de $12 \%$. As juntas coladas foram preparadas de acordo com a norma ASTM D 2339-98. Os valores da densidade básica mostraram uma tendência de aumento no sentido medula-casca e no sentido longitudinal não houve variação significativa. Os valores médios mais elevados de resistência ao cisalhamento e as menores percentagem de falha na madeira foram obtidos em juntas provenientes das posições próximas à casca e à base da tora. O comportamento da qualidade da colagem com adesivo resorcinolformaldeído na madeira de Eucalyptus grandis se mostrou bastante variável nas diferentes posições.
\end{abstract}

Palavras-chave: Eucalipto, juntas coladas, termoendurecedor.

\section{INTRODUCTION}

The use of wood in the manufacture of a wide variety of products is to a large degree due to advancements in bonding techniques. According to Marra (1980), around 70\% of all wood-derived products contain some type of adhesive which is added during the manufacture process. Such products include plywood, laminated beams, fiberboard, particleboard, paper products, furniture pieces etc.

The bonding properties of cell components both in wood and in other materials are conditional on a number of parameters relating to the physicochemical characteristics of the adhesive and relevant material, the bonding method, the geometric shape and size of pieces, and also the conditions to which the bonded pieces will be exposed while in use (MARRA 1992).

Basic wood density is considered an important parameter for bonding materials. The lower the density, the higher the permeability of a wood structure (HUNT \& GARRAT 1962), and probably the stronger the interfacial bonding between adhesive and wood (greater specific and mechanical adhesion) (MARRA 1992).

Several techniques are used in the manufacture of a vast array of wood-based products, among which is the glued laminated timber technique, one in which the quality of bonded joints is critical. Glued laminated timber is a structural component composed of several layers of

\footnotetext{
${ }^{1}$ Forest Engineer, M.Sc. in Wood Science and Technology - Departamento de Ciências Florestais - Universidade Federal de Lavras Cx. P. 3037 - 37200-000 - Lavras, MG, Brasil - vanessa.floresta@ hotmail.com

${ }^{2}$ Forest Engineer, Professor, Dr. in Forest Sciences - Departamento de Ciências Florestais - Universidade Federal de Lavras - Cx. P. 3037 - 37200-000 - Lavras, MG, Brasil - morif@ dcf.ufla.br

${ }^{3}$ Forest Engineer, Professor, Dr. in Forest Engineering - Departamento de Ciências Florestais - Universidade Federal de Lavras - Cx. P. 3037 - 37200-000 - Lavras, MG, Brasil - lourival@dcf.ufla.br
} 
dimensioned timber compressed and glued together with waterproof adhesive at varying pressures, with wood grain running parallel, and with members being scarf-jointed or finger-jointed whenever large structural spans have to be dealt with (PFEIL \& PFEIL 2003). One of the characteristics of these pieces is the possibility of combining different quality timbers (NIELSEN 1998). Successful results for products based on this technique are largely conditional on the adhesive being used. The adhesive should have bonding strength, stability and durability and these characteristics relate directly to the properties of the relevant timber.

A major limiting factor for glulam production in Brazil is the cost of adhesives. The most commonly used glues in the manufacture of structural wood products are phenolic adhesives and derivatives, and also resorcinolbased adhesives for outdoor uses. Resorcinol adhesive has excellent durability, high structural strength and cures at room temperature, and materials bonded with this adhesive are well known for their strength in enduring different types of conditions, including boiling water, high humidity and many types of solvents (DURAIRAJ 2005). Having much higher reactivity than phenol, it is nonetheless usually combined with phenol in equal amounts because of its high cost. Resorcinol adhesives can cost four to five times as much as phenolformaldehyde adhesives. In an attempt to reduce the cost of resorcinol adhesive, some researchers have been studying the strength behavior of wood joints bonded with the adhesive either diluted or applied to a reduced area. Nascimento et al. (2002), in a study about the behavior of wood-adhesive bonds in pine and eucalyptus, found that, for dilutions of up to $10 \%$ and $15 \%$ respectively, the performance of diluted resorcinol adhesive was similar to that obtained by using it undiluted.

Various wood species can be used in the above described technique, the quality and value of the final product being dependent on the species and adhesive being used. Many studies have been conducted on the use of timber from reforested stands for structural purposes, especially using adhesive as bonding agent, noting that timber from reforested stands can help reduce final product costs due to its fast growth capability and wide availability in comparison to native forests. Recent interest has been focused on adhesively bonded wood and particularly on glued laminated timber, noticeable by the large number of research studies being undertaken by the scientific community (NASCIMENTO et al. 2002).

Among timbers from reforested stands, genus Eucalyptus is a promising option for use in products of enhanced added value such as wood solids, including sawnwood, furniture pieces, structural components, processed timber for particleboard, fiberboard and laminated structures etc (LIMA 2006).

In 2007, Brazilian planted forests covered an area of around 6.0 million hectares. Eucalyptus accounted for $62.7 \%$ of this total, ranking 2nd among planted forest species intended for use in the engineered wood industry (ASSOCIAÇÃO BRASILEIRA DA INDÚSTRIA DE MADEIRA PROCESSADA E INDUSTRIAL-ABIMCI 2008). The growing use of eucalyptus sawnwood in Brazil calls for more in-depth evaluations of its characteristics and behavior when subjected to industrial processes (ABIMCI 2008). In terms of bonding properties, a variation exists in the behavior of eucalyptus wood depending on the position of the wood sheet relative to the log. A better understanding of this aspect will help achieve improved bonding quality, better performance, and cost reduction as a result.

This work aims to evaluate the quality of bonded joints, as obtained from three radial positions and from three longitudinal positions relative to the $\log$, in wood of Eucalyptus grandis W. Hill ex Maiden, using thermosetting resorcinol-formaldehyde adhesive, and also to determine variations in basic density depending on position, as well as to assess the influence of this variable on bonding properties.

\section{MATERIAL AND METHODS}

Wood of Eucalyptus grandis W. Hill ex Maiden was obtained from two trees (age 18 years and average DBH $23 \mathrm{~cm}$ ) cultivated in the municipality of Lavras, MG. A log was removed from the base of each tree, each $\log$ being 4 meters in length, then each log was cut into boards $25 \mathrm{~mm}$ in nominal thickness, as illustrated in Figure 1. Samples were taken close to the pith (a), close to the bark (c) and halfway between the two (b), and left to dry outdoors away from rain and direct sunlight. Once dry, they were cut into three adjacent pieces 1.3 meter in length each, along the longitudinal axis of the tree, respectively considered as log base, log middle and log top.

Cerne, Lavras, v. 16, n. 4, p. 443-449, out./dez. 2010 


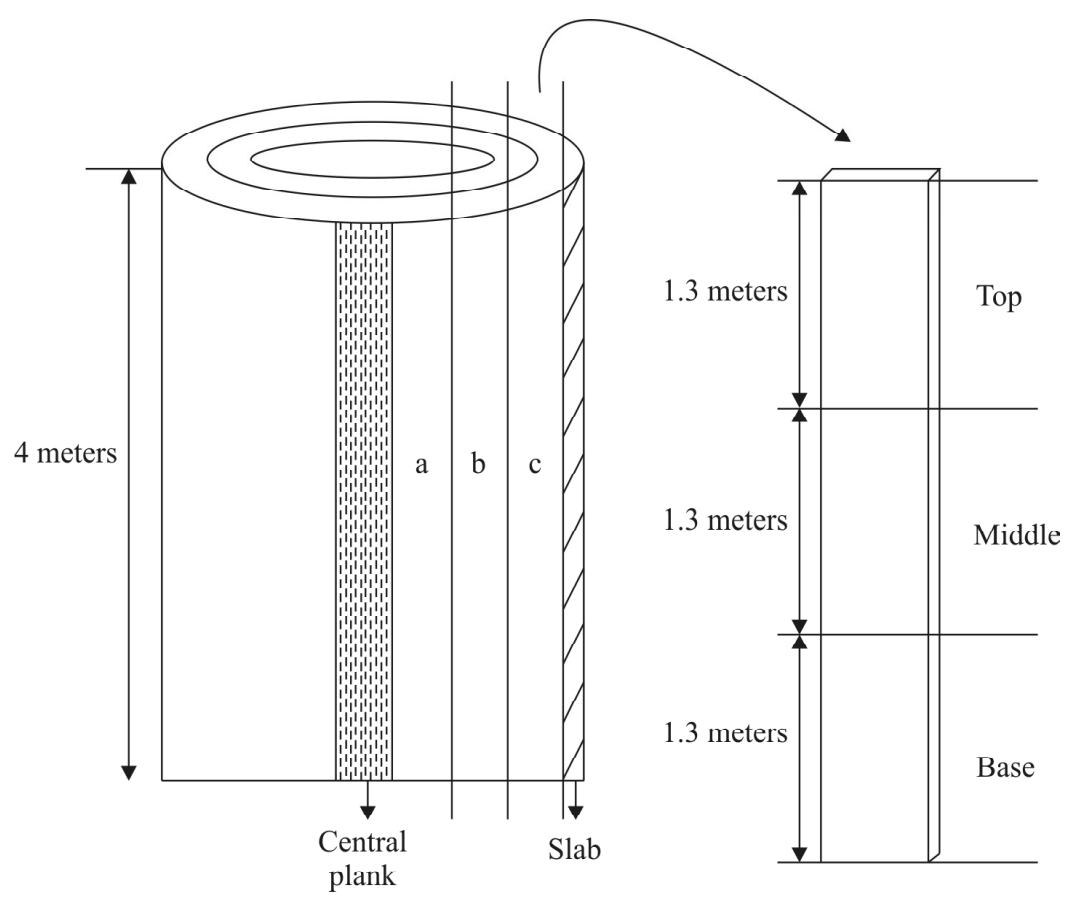

Figure 1 - Sketch of log cutting: A - area close to the pith; B - middle portion; C - area close to the bark.

Figura 1 - Esquema de obtenção das tábuas: A - região próxima à medula; $B$ - região intermediária; $C$ - região próxima à casca.

\subsection{Determination of basic density}

For determination of basic density, specimens were removed from representative longitudinal and radial positions, then submerged in distilled water and allowed time for full saturation of fibers. Specimens were then weighed and placed in a ventilated laboratory oven to reach a constant weight, and subsequently they were weighed using a scale accurate to $0.01 \mathrm{~g}$, following the procedure described in NBR11941 (ASSOCIAÇÃO BRASILEIRA DE NORMAS TÉCNICAS-ABNT 2003).

2.2 Preparation of bonded joints, determination of physicochemical adhesive properties and evaluation of bonding strength at different positions relative to the $\log$

Boards were processed into thin strips $0.5 \times 10 \times 30$ $\mathrm{cm}$ in size (thickness $\mathrm{x}$ width $\mathrm{x}$ length), intended for assembly of bonded joints in agreement with standard ASTM D 2339 (AMERICAN SOCIETY FOR TESTING AND MATERIALS-ASTM 2000). The thin strips were placed in a temperature-controlled chamber at $25 \pm 2{ }^{\circ} \mathrm{C}$ and $60 \pm 2 \%$ $\mathrm{RH}$ prior to bonding, until they reached an average moisture content of $12 \%$. The adhesive used was resorcinol- formaldehyde (Cascophen-RS-216 from Alba Química) with addition of hardener (FM) at a rate of one part of hardener to five of adhesive. The spread rate of adhesive was $250 \mathrm{~g} / \mathrm{m}^{2}$, applied in double lines. The adhesive was prepared in advance and then spread over the wood surfaces, with strips being immediately joined together and left to rest for about 15 minutes, after which time they were cold pressed at $12 \mathrm{kgf} / \mathrm{cm}^{2}$ for 24 hours. A total of 36 pairs of joints were prepared for each tree, in a complete $3 \times 3 \times 3$ factorial design combining radial and longitudinal positions, with three replications.

Once bonded, joints were again placed in the temperature-controlled chamber under the same conditions as above for about 15 days, and subsequently each was processed into 12 specimens. Out of the total, $20 \%$ of the specimens were selected and subjected to an accelerated aging test (water at $100^{\circ} \mathrm{C}$ for 4 hours - heat at $63^{\circ} \mathrm{C}$ for 20 hours - water at $100^{\circ} \mathrm{C}$ for 4 hours - cooling). All specimens were subjected to shear stress testing using a ContencoPavitest pneumatic loading system, installed in the experimental unit for wood panel production of DCF-UFLA, Lavras, MG. After rupture, four staff members of the wood science and technology division quantified the percentage of wood failure according to standard ASTM D3110 (ASTM 
1994a). Percentages of wood failure were subjected to arcsine transformation for data normalization. The statistical method used in this experiment was completely randomized design (CRD) and experimental results were interpreted using analysis of variance and the Scott-Knott test at the 95\% probability level.

Physicochemical properties of the adhesive were also determined, including solids content, $\mathrm{pH}$, viscosity and setting time. To determine solids content, an adapted version of standard ASTM D1582-60 (ASTM 1994b) was used. To determine $\mathrm{pH}$, a $\mathrm{pH}$ meter was used at a temperature of $25^{\circ} \mathrm{C}$. Viscosity was determined using a Copo Ford viscometer with an orifice diameter of $4 \mathrm{~mm}$. To determine the setting time, $10 \mathrm{~g}$ of adhesive was weighed in a test tube ( $15 \mathrm{~cm}$ high $\mathrm{x} 2 \mathrm{~cm}$ wide) and manually mixed using a glass stirrer. Setting time was considered as being the time interval between first stir and full hardening of the adhesive, that is, the point where stirring was no longer possible.

\section{RESULTS AND DISCUSSION}

\subsection{Basic wood density}

Mean values of basic density for longitudinal and radial positions in wood of Eucalyptus grandis W. Hill ex
Maiden are provided by an illustrative sketch of the tree log in Figure 2.

The mean value $\left(0.58 \mathrm{~g} / \mathrm{cm}^{3}\right)$ found in this study was higher than the value found by Silva et al. (2004), who worked with wood of Eucalyptus grandis at four different ages using various radial positions and obtained $0.47 \mathrm{~g} / \mathrm{cm}^{3}$ as mean value for age 20 years. Figure 2 reveals an increasing tendency in the pith-tobark direction for mean values of basic density. Trevisan et al. (2008), working with wood of Eucalyptus grandis at age 14 years, found lower mean values in the pith area $\left(0.37 \mathrm{~g} / \mathrm{cm}^{3}\right)$, gradually increasing toward the outermost area of the $\log \left(0.43 \mathrm{~g} / \mathrm{cm}^{3}\right)$. Longitudinally, mean values of basic density did not show a significant variation. Basic density variability can result from changes in the proportion of vases and thickness of the cell walls of fibers. The increasing density in the pithto-bark direction may have resulted, for instance, from cell wall thickening or from an increasing proportion of fibers relative to vases.

\subsection{Physicochemical properties of the adhesive and strength to shear stress testing}

Results of physicochemical properties of the adhesive are shown in Table 1.

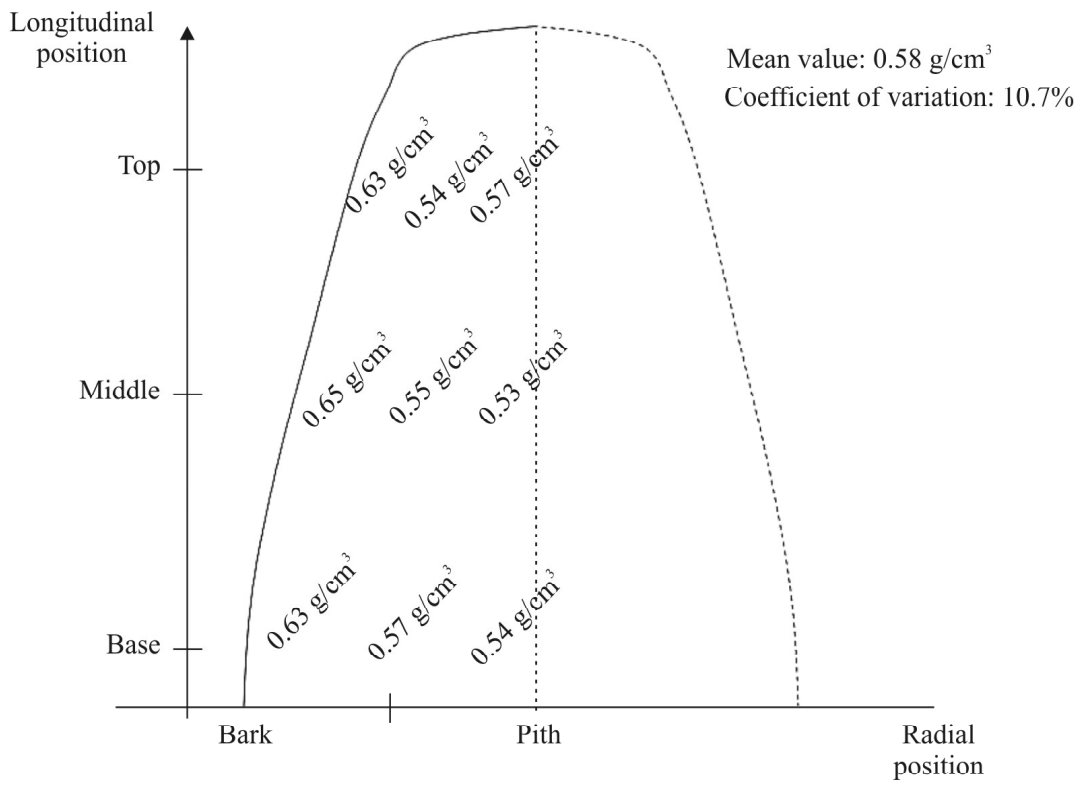

Figure 2 - Illustrative sketch of the $\log$ with basic density values $\left(\mathrm{g} / \mathrm{cm}^{3}\right)$ for longitudinal and radial gradients.

Figura 2 - Esquema ilustrativo da tora da árvore contendo os valores de densidade básica $\left(\mathrm{g} / \mathrm{cm}^{3}\right)$ para as posições longitudinal e radial.

Cerne, Lavras, v. 16, n. 4, p. 443-449, out./dez. 2010 
Table 1 - Physicochemical properties of resorcinolformaldehyde adhesive.

Tabela 1 - Propriedades físico-químicas do adesivo resorcinolformaldeído.

\begin{tabular}{lc}
\hline \multicolumn{2}{c}{ Properties } \\
\hline Adhesive aspect & Dark liquid \\
Solids content (\%) & 59.4 \\
Viscosity (cp) & 5488.3 \\
Ph & 7.1 \\
Setting time (hours) & 8 (approximately) \\
\hline
\end{tabular}

Table 2 provides the result of a factorial ANOVA to evaluate the effect of positions on strength to shear stress testing, dry and after boil.

Table 2 - Factorial ANOVA for strength to dry and after boil shear stress testing.

Tabela 2 - Resumo da ANOVA fatorial para tensão de ruptura ao ensaio de cisalhamento seco (tr seco) e após fervura (tr após fervura).

\begin{tabular}{lccc}
\hline Source & $\begin{array}{c}\text { Degree of } \\
\text { freedom }\end{array}$ & Dry & After boil \\
\cline { 3 - 4 } & 2 & 0.0953 & $0.873389^{*}$ \\
Longitudinal & 2 & $8.31847^{*}$ & $13.162702^{*}$ \\
Radial & 4 & $0.36881^{*}$ & 0.555702 \\
Long*Rad & & 6.33 & 11.43 \\
C.V. $(\%)$ & & Mean square \\
\hline
\end{tabular}

$\mathrm{e}^{*}$ : Significant at the $5 \%$ level, by the $\mathrm{F}$ test.

As regards strength to dry shear stress, a significant effect was found from the interaction of positions and from the radial position, while as regards after boil testing, a significant effect was found from each position in isolation.

Table 3 provides mean values of strength to dry shear stress.

As regards the longitudinal breakdown within the radial gradient for the variable in question, a significant effect was found only for the position close to the pith, with the lowest value (3.42 $\mathrm{MPa})$ being found for the position close to the top. As regards the radial breakdown within the longitudinal gradient, a significant effect was found for longitudinal position on radial position, with the highest value (5.93 $\mathrm{MPa})$
Table 3 - Mean values of strength to dry shear stress (MPa).

Tabela 3 - Valores médios de tensão de ruptura do ensaio de cisalhamento seco $(\mathrm{MPa})$.

\begin{tabular}{lcccc}
\hline Position & Bark & Halfway & Pith & Mean \\
\hline Base & $5.83 \mathrm{aA}$ & $4.64 \mathrm{aB}$ & $3.93 \mathrm{aC}$ & 4.80 \\
Middle & $5.93 \mathrm{aA}$ & $4.47 \mathrm{aB}$ & $4.14 \mathrm{aB}$ & 4.84 \\
Top & $5.49 \mathrm{aA}$ & $5.04 \mathrm{aA}$ & $3.42 \mathrm{bB}$ & 4.65 \\
Mean & 5.75 & 4.72 & 3.83 & \\
\hline
\end{tabular}

Means followed by the same letter do not statistically differ at the $95 \%$ probability level, by the Scott-Knott test. The first letter (lowercase) refers to longitudinal breakdown within the radial gradient along the vertical axis of the table. The second letter (uppercase) refers to radial breakdown within the longitudinal gradient along the horizontal axis of the table.

being found for the position close to the bark, while the lowest (3.43 MPa), close to the pith. This result is compatible with the findings of Vital et al. (2006), who obtained higher mean values of strength to shear stress close to the bark than close to the pith. The difference found for radial positions can be attributed to wood density or to anatomical characteristics. The pith area is formed by juvenile wood which typically has low density, thin cell walls and low percentage of latewood. This factor may have resulted in deeper penetration of the adhesive into the sheets, resulting in excessive glue absorption due to porosity and, consequently, inferior bonding strength. Another factor that may have contributed to inferior bonding strength there is the presence of heartwood and tylosis, obstructing wood permeability to the adhesive.

In comparing mean values of strength to shear stress to values found by other authors for the same species (LIMA et al. 2008, NASCIMENTO et al. 2002, VITAL et al. 2006), values in this study were lower, yet several factors may have contributed to this difference, including standard or procedure used, glue quantity, tree age, location of tree stand and test type. Procedures to test shear strength may differ as to specimen size, resulting in higher or lower strength values accordingly. Larger specimens may show greater strength on account of having larger surfaces. As for glue quantity, where larger quantities are used per unit area, adhesive mobility may increase and, consequently, strength is enhanced. Table 4 provides mean values of strength to shear stress after boil, for longitudinal and radial positions.

Cerne, Lavras, v. 16, n. 4, p. 443-449, out./dez. 2010 
Table 4 - Mean values of strength to shear stress testing after boil (MPa), for longitudinal and radial positions.

Tabela 4 - Valores médios de tensão de ruptura ao ensaio de cisalhamento após fervura (MPa) de acordo com as posições longitudinal e radial da tora.

\begin{tabular}{lclc}
\hline \multicolumn{2}{c}{ Longitudinal } & \multicolumn{2}{c}{ Radial } \\
\hline Position & After boil & Position & After boil \\
\hline Base & $4.20 \mathrm{a}$ & Bark & $4.88 \mathrm{a}$ \\
Middle & $4.12 \mathrm{a}$ & Halfway & $4.17 \mathrm{~b}$ \\
Top & $3.75 \mathrm{~b}$ & Pith & $3.02 \mathrm{c}$ \\
\hline
\end{tabular}

Means followed by the same letter do not differ statistically at the $95 \%$ probability level, by the Scott-Knott test.

The lowest value of strength to shear stress testing after boil in the longitudinal gradient was $3.75 \mathrm{MPa}$, for the $\log$ top. In the radial gradient, the highest value was 4.88 $\mathrm{MPa}$ in the area close to the bark, and the lowest was 3.02 MPa in the area close to the pith. The same tendency was found for strength to dry shear stress.

\subsection{Percentage of wood failure}

Table 5 provides the result of a factorial ANOVA to evaluate the effect of position relative to the log on the percentage of wood failure when subjected to shear stress, dry and after boil.

Table 5 - Factorial ANOVA for percentage of wood failure when subjected to dry and after boil shear stress.

Tabela 5 - Resumo da ANOVA fatorial para a percentagem de falha na madeira em relação à tensão de ruptura ao ensaio de cisalhamento seco e após fervura.

\begin{tabular}{lccc}
\hline Source & $\begin{array}{c}\text { Degree of } \\
\text { freedom }\end{array}$ & $\begin{array}{c}\text { Mean } \\
\text { square }\end{array}$ & $\begin{array}{c}\text { Mean } \\
\text { square }\end{array}$ \\
\cline { 3 - 4 } Longitudinal & 2 & $0.047315^{*}$ & 0.019296 \\
Radial & 2 & $0.280493^{*}$ & $0.492469^{*}$ \\
Long*Rad & 4 & 0.012854 & 0.035626 \\
\hline CV $(\%)$ & & 5.9 & 18.34 \\
\hline
\end{tabular}

$\mathrm{e}^{*}$ : Significant at the $5 \%$ level, by the $\mathrm{F}$ test.

As regards wood failure when subjected to dry shear stress, no effect was found from the interaction of positions, while after boil an effect was found only from radial position.
Table 6 provides mean values of wood failure percentage under dry and after boil shear stress testing, for longitudinal and radial positions.

Table 6 - Mean values of wood failure percentage under dry and after boil shear stress testing, for longitudinal and radial positions.

Tabela 6 - Valores médios de percentagem de falha na madeira em relação à tensão de ruptura ao ensaio de cisalhamento seco e após fervura para as posições longitudinal e radial.

\begin{tabular}{lcclcc}
\hline \multicolumn{3}{c}{ Longitudinal (\%) } & \multicolumn{3}{c}{ Radial (\%) } \\
\hline Position & Dry & $\begin{array}{c}\text { After } \\
\text { boil }\end{array}$ & Position & Dry & $\begin{array}{c}\text { After } \\
\text { boil }\end{array}$ \\
\hline Base & $86.34 \mathrm{~b}$ & $93.08 \mathrm{a}$ & Bark & $77.78 \mathrm{c}$ & $83.01 \mathrm{~b}$ \\
Middle & $92.73 \mathrm{a}$ & $95.23 \mathrm{a}$ & Halfway & $93.63 \mathrm{~b}$ & $96.50^{\mathrm{a}}$ \\
Top & $94.36 \mathrm{a}$ & $96.23 \mathrm{a}$ & Pith & $97.91 \mathrm{a}$ & $99.53^{\mathrm{a}}$ \\
\hline
\end{tabular}

Means followed by the same letter do not differ statistically at the $95 \%$ probability level, by the Scott-Knott test.

The lowest value of wood failure percentage when subjected to dry shear stress in the longitudinal gradient was found close to the log base $(86.34 \%)$. In the radial gradient, the lowest value was found close to the bark $(77.78 \%)$ and the highest was found close to the pith (97.91\%). According to ASTM (2000), high values of wood failure percentage suggest good bonding performance, demonstrating that the bonding forces of the adhesive and also specific adhesion in the wood-adhesive interface are greater than wood strength itself. In this work, however, high values of failure percentage were found in the area close to the log top, a sign of low strength to shear stress testing. This probably happened because the area concentrates juvenile wood and thus has inferior physico-mechanical properties.

The lowest value of wood failure percentage when subjected to shear stress testing after boil was $83.01 \%$, close to the bark. This area showed high strength to shear stress, and thus low failure percentage, as mentioned. This may have happened because of the adhesive being used, which probably conferred improved strength on that particular area, or maybe because of higher basic density in that particular area.

The percentage of wood failure was noted to increase in bonded joints subjected to accelerated aging cycles (after boil test). As this involves exposure to very high temperatures, this may have contributed to adhesive loosening in the wood structure of the bonded joints,

Cerne, Lavras, v. 16, n. 4, p. 443-449, out./dez. 2010 
reducing the adhesion area and weakening bonding performance, thus increasing the percentage of wood failure.

\section{CONCLUSIONS}

Basic wood density increased in the pith-to-bark gradient while in the base-to-top gradient it did not show significant differences between positions.

Mean values of shear strength (dry and after boil) in the base-to-top gradient were higher close to the log base and lower close to the log top. As regards percentage of wood failure, the reverse happened.

Mean values of shear strength (dry and after boil) in the pith-to-bark gradient were higher close to the bark and lower close to the pith. As regards percentage of wood failure, the reverse happened.

The bonding performance of resorcinolformaldehyde adhesive in wood of Eucalyptus grandis was found to vary considerably in different positions relative to the $\log$.

\section{ACKNOWLEDGMENT}

The authors wish to thank the National Council for Scientific and Technological Development (Cnpq).

\section{BIBLIOGRAPHICAL REFERENCES}

AMERICAN SOCIETY FOR TESTING AND MATERIALS Annual book of ASTM standards: adhesives: D2339-98. Philadelphia, 2000. 600 p.

AMERICAN SOCIETY FOR TESTING AND MATERIALS. Annual book of ASTM standards: adhesives: D-3110. Philadelphia, 1994a. 600 p.

AMERICAN SOCIETY FOR TESTING AND MATERIALS. Annual book of standards: D1582-60. Denver: ASTM, 1994b.

ASSOCIAÇÃO BRASILEIRA DA INDÚSTRIA DE MADEIRA PROCESSADA E INDUSTRIAL. Madeira processada mecanicamente: estudo setorial. 2008. Disponível em: $<\mathrm{http}: / /$

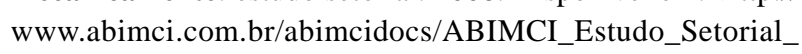
2008.pdf >. Acesso em: 23 out. 2009.

ASSOCIAÇÃO BRASILEIRA DE NORMAS TÉCNICAS. NBR 11941: madeira, determinação da densidade básica. Rio de Janeiro, 2003. 6 p.

DURAIRAJ, R. B. Resorcinol: chemistry, technology and applications. Berlin: Springer, 2005. 748 p.
HUNT, G. M.; GARRAT, G. A. Preservacion de la madera. Barcelona: Salvat, 1962. 486 p.

LIMA, C. K. P. Avaliação da qualidade de juntas coladas da madeira de clones de Eucalyptus. 2006. 89 p. Dissertação (Mestrado em Engenharia Florestal) - Universidade Federal de Lavras, Lavras, 2006.

LIMA, C. K. P.; MORI, F. A.; MENDES, L. M.; TRUGILHO, P. F.; MORI, C. L. S. O. Colagem da madeira de clones de Eucalyptus com três adesivos comerciais. Scientia Forestalis, Piracicaba, v. 36, n. 77, p. 73-77, mar. 2008.

MARRA, A. A. Technology of wood bonding: principles and practice. New York: V. N. Reinhold, 1992. 454 p.

MARRA, G. G. The role of adhesion and adhesives in the wood products industry. In: SYMPOSIUM ON WOOD ADHESIVES RESEARCH, APPLICATION AND NEEDS, 1., 1980, Madison. Proceedings... Madison: Forest Products Laboratory, 1980. p. 1-8.

NASCIMENTO, A. M.; LELIS, R. C. C.; COSTA, D. L.; OLIVEIRA, C. S. Comportamento de ligações adesivas em madeiras de reflorestamento. Floresta e Ambiente, Rio de Janeiro, v. 9, n. 1, p. 54-62, jan./dez. 2002.

NIELSEN, I. R. Utilização da madeira comercial do híbrido de Eucalyptus urophylla S.T. Blake $\mathrm{x}$ Eucalyptus grandis Hill ex Maiden na confecção de vigas laminadas coladas. 1998. 109 p. Dissertação (Mestrado em Engenharia Florestal) Universidade Federal do Paraná, Curitiba, 1998.

PFEIL, W. E.; PFEIL, M. Estruturas de madeira. 6. ed. Rio de Janeiro: LTC, 2003. 224 p.

SILVA, J. C.; OLIVEIRA, J. T. S.; TOMAZELLO FILHO, M.; KEINERT JÚNIOR, S.; MATOS, J. L. M. de. Influência da idade e da posição radial na massa específica básica da madeira de Eucalyptus grandis Hill ex. Maiden. Floresta, Curitiba, v. 34, n. 1, p. 13-22, 2004.

TREVISAN, R.; HASELEIN, C. R.; MELO, R. R.; STANGERLIN, D. M.; BELTRAME, R.; GATTO, D. A.; CALEGARI, L. Variação radial da massa específica básica da madeira de Eucalyptus grandis W. Hill ex Maiden. Floresta, Curitiba, v. 38, n. 3, p. 553-559, jul./set. 2008.

VITAL, B. R.; MACIEL, A. S.; DELLA LUCIA, R. M. Qualidade de juntas coladas com lâminas de madeira oriundas de três regiões do tronco de Eucalyptus grandis, Eucalyptus saligna e Pinus elliottii. Árvore, Viçosa, v. 30, n. 4, p. 637-644, 2006.

Cerne, Lavras, v. 16, n. 4, p. 443-449, out./dez. 2010 
